\title{
Lateral Flow Serodiagnosis in the Double-Antigen Sandwich Format: Theoretical Consideration and Confirmation of Advantages
}

\author{
Dmitriy V. Sotnikov*, Anatoly V. Zherdev (D) and Boris B. Dzantiev (D)
}

A.N. Bach Institute of Biochemistry, Research Center of Biotechnology of the Russian Academy of Sciences, Leninsky Prospect 33, 119071 Moscow, Russia; zherdev@inbi.ras.ru (A.V.Z.); dzantiev@inbi.ras.ru (B.B.D.)

* Correspondence: sotnikov-d-i@mail.ru; Tel.: +7-495-9543142

Citation: Sotnikov, D.V.; Zherdev, A.V.; Dzantiev, B.B. Lateral Flow Serodiagnosis in the Double-Antigen Sandwich Format: Theoretical Consideration and Confirmation of Advantages. Sensors 2021, 21, 39. https://dx.doi.org/10.3390/ s21010039

Received: 19 November 2020 Accepted: 16 December 2020 Published: 23 December 2020

Publisher's Note: MDPI stays neutral with regard to jurisdictional claims in published maps and institutional affiliations.

Copyright: (c) 2020 by the authors. Licensee MDPI, Basel, Switzerland. This article is an open access article distributed under the terms and conditions of the Creative Commons Attribution (CC BY) license (https: / / creativecommons.org/ licenses/by/4.0/).

\begin{abstract}
Determination of the presence in the blood of antibodies specific to the causative agent of a particular disease (serodiagnosis) is an effective approach in medical analytical chemistry. Serodiagnostics performed in the lateral flow immunoassay format (immunochromatography) meet the modern requirements for point-of-care testing and are supported by existing technologies of large-scale diagnostic tests production, thus increasing the amount of attention in a tense epidemiological situation. For traditional lateral flow serodiagnostics formats, a large number of nonspecific immunoglobulins in the sample significantly reduces the degree of detectable binding. To overcome these limitations, an assay based on the formation of immobilized antigen-specific antibody-labeled antigen complexes detection was proposed. However, the requirements for its implementation, providing maximum sensitivity, have not been established. This article describes the mathematical model for the above assay. The influence of the ratio of reagent concentrations on the analysis results is considered. It is noted that the formation of specific antibody complexes with several labeled antigens is the main limiting factor in reducing the detection limit, and methods are proposed to minimize this factor. Recommendations for the choice of the assay conditions, following from the analysis of the model, are confirmed experimentally.
\end{abstract}

Keywords: point-of-care assay; membrane tests; immunochromatography; lateral flow immunoassay; immune response; detection of antibodies; antigen-antibody reactions; mathematical modelling; assay sensitivity; limit of detection

\section{Introduction}

The presence of antibodies specific to the causative agent of a certain disease in the blood (serodiagnosis) indicates the contact between the organism and the pathogen, and, for many diseases, it is considered an effective diagnostic parameter [1-3]. The advantages of such diagnostics in comparison with the detection and identification of the pathogen itself consist in the relatively simple sampling, the reproducible results that do not depend on the choice of the sampling site or that slowly change for the patient over time, and the excluded need to grow the pathogen until it reaches the detectable concentration. Serodiagnostics is actively used for many widespread and socially significant infections, including tuberculosis, human immunodeficiency virus, and more [4-8]. Particular interest in this diagnostic method has arisen this year due to the coronavirus pandemic [9-11].

Serodiagnostics can be implemented in different formats; however, today two of them dominate in mass practice-microplate enzyme immunoassay and immunochromatographic analysis - which correspond to their leading place in relation to immunodiagnostics in general [12-14]. At the same time, recent years have seen the accelerated development of point-of-care diagnostic tools, which make it possible to carry out methodically simple testing directly at the sampling site and quickly obtain results [15-18]. This requirement is fully met by immunochromatographic analysis (lateral flow immunoassay). All reagents 
required for the assay are pre-applied to the test strip (a composite of several membranes). Contact of the sample with this test strip initiates the movement of liquid along the pores of the membranes and analytical reactions with the applied reagents, including reagents containing a colored label. Most often, nanodispersed gold particles are used as such a label due to their intense color, ease of preparation, and modification [19-21]. As a result of these processes, labeled colored immune complexes are formed in certain zones of the test strip. A visual assessment of the presence or absence of coloration of these zones allows us to make conclusions about the test results [22,23].

For serodiagnostics, several formats are possible, differing in the location and labeling of immunoreagents. The most known format consists of immobilizing an antigen (specific for a given pathogen) in the analytical zone and labeling an immunoglobulin-binding reagent-anti-species antibodies, bacterial immunoglobulin-binding proteins (protein A, protein G), etc. [24-29]. The presence of specific antibodies to the pathogen in the sample leads to the formation of a detectable complex of immobilized antigen molecules, specific antibodies and labeled immunoglobulin-binding protein (Figure 1A). When carrying out such serodiagnostics, a reliable difference in results is achieved for samples containing and not containing specific antibodies. However, the intensity of the recorded color is often low, which prevents a correct assessment of the results obtained. The reason for this effect is that the labeled immunoglobulin-binding protein binds to all immunoglobulins in the tested blood or serum, of which only a few percent are specific to this pathogen $[30,31]$. The reaction of immunoglobulin-binding proteins with nonspecific immunoglobulins reduces the proportion of the label that is capable of participating in the formation of a detectable complex of antigen-specific antibody-immunoglobulin-binding protein label when the fluid passes through the analytical zone.

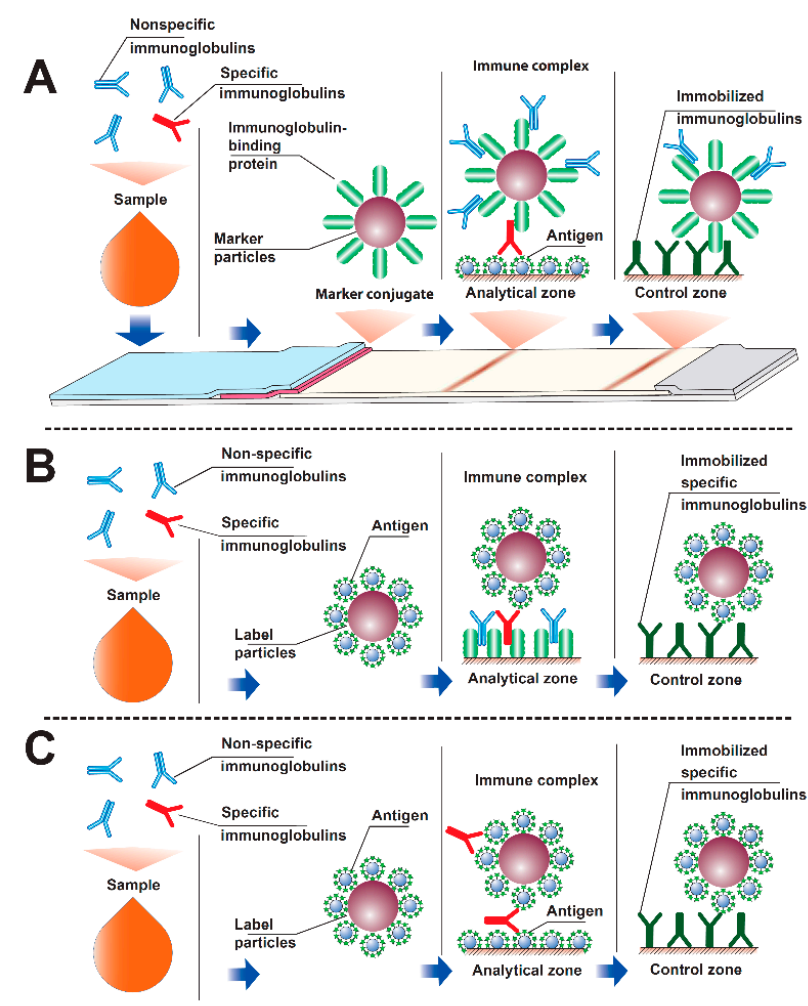

Figure 1. The three serodiagnostic immunochromatography formats: (A) with labeled immunoglobulin-binding protein and immobilized antigen in the analytical zone; (B) with labeled antigen and immobilized immunoglobulin-binding protein in the analytical zone; (C) with labeled antigen and immobilized antigen in the analytical zone (see additional comments in the paper). 
To overcome this limitation, an alternative immunochromatographic serodiagnostics format has been proposed, in which the label is conjugated to the antigen, and an immunoglobulin-binding protein is sorbed in the analytical zone [32-37]. This approach prevents the inclusion of the label in complexes with nonspecific immunoglobulins. The problem of signal attenuation, however, remains, because nonspecific immunoglobulins react with immunoglobulin-binding proteins in the analytical zone (Figure 1B). However, the sorption capacity of this zone on the test strip is significantly higher (about an order of magnitude) than the sorption capacity of the preparations of nanodispersed marker particles [36]. Therefore, the binding in the analytical zone of nonspecific antibodies to a lesser extent affects the formation of detectable complexes: immunoglobulin-binding protein-specific antibody-antigen-label.

To eliminate the influence of nonspecific immunoglobulins in the sample on the results of serodiagnostic immunochromatography, a third analysis format has been proposed, in which antigen is present both in the analytical zone and in combination with the label [33,38-40]. Due to several valencies of antibodies (2 for IgG, IgE and serum $\operatorname{IgA}$, 10 for $\operatorname{IgM})$, in this format, antigen-specific antibody-antigen-tag complexes can be formed in the analytical zone (Figure 1C). This scheme excludes the interaction of nonspecific immunoglobulins with components involved in the formation of a detectable complex. However, obstacles to the inclusion of a label in the detected complex exist in this case as well because a specific antibody can use its valences to bind only to labeled antigens. There are currently no recommendations in the literature to minimize these effects.

Taking into account the relevance of the requirement to minimize cases of false negative serodiagnostics results, the task of increasing its analytical sensitivity is becoming extremely important. However, the empirical variation of components concentrations and conditions of their interaction is an extremely laborious task. In addition, the choice for one test system may turn out to be far from optimal when switching to another test system (working with another antigenic preparation or with another infection). The process of developing test systems can be intensified using mathematical models because examining the model allows for identifying the key factors affecting the characteristics of the test system, understanding the reasons for the observed negative effects, and proposing ways to eliminate them. The practical application of the results of immunoanalytical systems modeling have been considered in a number of recent works and are summarized in previous reviews [41-46]; however, the regularities of the functioning of the test system with detected immobilized antigen-specific antibody-labeled antigen complexes have not been previously analyzed. Due to the above-mentioned potential advantages of such serodiagnostics, the presented work includes its theoretical consideration, identification, and verification of the regularities of the formation of detected complexes, and characteristics of factors influencing the analytical parameters of the test systems.

\section{Materials and Methods}

\subsection{Reactants and Membranes}

This study used recombinant protein A produced by Imtek (Moscow, Russia); Tween20, sodium azide; N-(3-dimethylaminopropyl)-N'-ethylcarbodiimide (EDC), sulfo-Nhydroxysuccinimide (sulfo-NHS), and chloroauric from from Sigma-Aldrich (St. Louis, MO, USA); and bovine serum albumin (BSA) from Boval BioSolutions (Cleburne, TX, USA). Recombinant antigen of Mycobacterium tuberculosis with m.w. 38 kDa (Ag78, antigen 5, PhoS, Rv0934) came from Arista Biologicals Inc. (Allentown, PA, USA). Monoclonal antibodies HTM81 against the given protein came from the Center for Molecular Diagnostics and Therapy (Moscow, Russia). All salts were of chemical or analytical grade. Water was purified using a MilliQ unit from Millipore (Bedford, MA, USA). 
To prepare immunochromatographic test systems, an mdi Easypack kit (Advanced Microdevices, Ambala Cantt, India) was used, which included working membranes CNPH90 with pores of $15 \mu \mathrm{m}$, a support for conjugate PT-R5, a membrane for applying samples FR1 (0.6), a final adsorbent membrane AP045, and a laminating protective film on an adhesive basis MT-1.

\subsection{Gold Nanoparticles Preparation}

To obtain gold nanoparticles with the expected average diameter near $20 \mathrm{~nm}, 2.95 \mathrm{~mL}$ of $0.34 \%$ chloroauric acid was added to $97.5 \mathrm{~mL}$ of boiling deionized water. The mixture was boiled for $2 \mathrm{~min}$ while stirring. Then $1.44 \mathrm{~mL}$ of $1 \%$ sodium citrate solution was added, stirred, boiled for $30 \mathrm{~min}$, and cooled for storage at $+4{ }^{\circ} \mathrm{C}$.

\subsection{Transmission Electron Microscopy}

The gold nanoparticles preparation was applied onto nets (300 mesh) (Pelco International, Redding, CA, USA) covered with a polyvinyl formal film dissolved in chloroform. To obtain the images, a CX-100 microscope (Jeol, Tokyo, Japan) was used at an acceleration voltage of $80 \mathrm{kV}$. Photographs were digitally analyzed using the Image Tool software.

\subsection{Immobilization of Rv0934 Antigen on Gold Nanoparticles}

The antigen was dialyzed against 1000 -fold of $10 \mathrm{mM}$ carbonate buffer, $\mathrm{pH}=9.0$. To the gold nanoparticles solution $\left(\mathrm{D}_{520}=1.0\right), 0.1 \mathrm{M} \mathrm{K}_{2} \mathrm{CO}_{3}$ was added until a $\mathrm{pH}=9.0$ was reached, and then the Rv0934 antigen at a concentration of $10 \mu \mathrm{g} / \mathrm{mL}$ was added. The mixture was incubated for $10 \mathrm{~min}$ at room temperature and stirred, after which a 10\% aqueous BSA solution was added, for a final concentration of $0.25 \%$.

The gold nanoparticles were separated from non-bound protein by 30-min centrifugation at $6.000 \times g$, resuspending in $50 \mathrm{mM} \mathrm{K}$-phosphate buffer, $\mathrm{pH} 7.4$, with $0.1 \mathrm{M} \mathrm{NaCl}$ (PBS) containing $0.25 \%$ BSA. The preparations were stored at $4{ }^{\circ} \mathrm{C}$.

\subsection{Application of Reagents to Immunochromatographic Membranes}

To form the analytical zone on the CNPH90 working membrane, the M. tuberculosis Rv0934 antigen was used. On $1 \mathrm{~cm}$ of the band, $1 \mu \mathrm{L}$ of an antigen solution $(1.0 \mathrm{mg} / \mathrm{mL}$ in $50 \mathrm{mM}$ phosphate buffer, $\mathrm{pH}$ 7.4) was applied (according to Figure 1C "analytical zone" compartment). To form the control zone, antibodies HTM81 were applied to the working membrane at a concentration of $0.5 \mathrm{mg} / \mathrm{mL}$ (Figure 1C "control zone" compartment). The gold nanoparticles conjugate with the Rv0934 antigen (according to Figure 1C "Labeled antigen-nanoparticle" conjugate) was applied on the PT-R5 support at a dilution corresponding to D520 from 1.25 to 10.0, in a volume of $8 \mu \mathrm{L}$ per $\mathrm{cm}$ of band. To apply the reagents, an IsoFlow dispenser (Imagene Technology, Hanover, NH, USA) was used.

\subsection{Manufacturing of Immunochromatographic Test Systems}

After applying the reagents, the membranes were dried in air at $20-22{ }^{\circ} \mathrm{C}$ for at least $20 \mathrm{~h}$. A membrane composite was assembled, from which strips $3.5 \mathrm{~mm}$ wide were obtained, using an Index Cutter-1 guillotine cutter (A-Point Technologies, Gibbstown, NJ, USA). The test strips were placed in plastic cassettes, and the bags made of laminated aluminum foil were hermetically sealed with silica gel as a desiccant. Cutting and packing was implemented at $20-22{ }^{\circ} \mathrm{C}$ in a special room with a relative humidity of not more than $30 \%$. The packaged test strips were stored at $20-22{ }^{\circ} \mathrm{C}$. 


\subsection{Immunochromatographic Analysis}

The assay was carried out at room temperature. The bag was opened, and the test strip was placed on a horizontal surface. One drop of blood serum and then 3 drops of PBS containing 1\% Tween-20 were added. After $10 \mathrm{~min}$, the assay result was monitored. The binding of the label was quantitatively assessed using a portable digital video analyzer "Reflekom" (Synteco, Moscow, Russia).

\subsection{Determination of Kinetic and Equilibrium Parameters of Interactions between Immunoreagents}

To characterize the antigen-antibody interaction, a biosensor approach based on surface plasmon resonance was used. Measurements were performed on a BIAcore $X$ (Biacore International, Uppsala, Sweden) using a CM5 chip with a carboxylated dextrancoated surface. Initially, the carboxyl groups of dextran were activated using a mixture of ethylcarbodiimide + hydroxysuccinimide (EDC + NHS), which formed short-lived ether groups, which then reacted with the amino groups of the ligand to form an amide bond. The activation was carried out by passing a mixture of activators from concentrations of $0.05 \mathrm{M} \mathrm{EDC} / 0.2 \mathrm{M}$ NHS through analytical and reference cells for $10 \mathrm{~min}$ at a flow rate of $10 \mu \mathrm{L} / \mathrm{min}$.

Antibodies HTM81 against the Rv0934 antigen were dissolved in $10 \mathrm{mM}$ sodium citrate buffer, $\mathrm{pH} 4.0$, to a concentration of $200 \mu \mathrm{g} / \mathrm{mL}$. The solution was passed only through the analytical cell; the reference cell remained closed. The passed volume of the solution was $80 \mu \mathrm{L}$. Unreacted activated groups in the analytical cell and the reference cell were blocked to prevent nonspecific interaction with $1 \mathrm{M}$ ethanolamine passed for $10 \mathrm{~min}$ at a flow rate of $10 \mu \mathrm{L} / \mathrm{min}$. Antigen samples were passed over the surface of the modified chip through the analytical and control cells at a flow rate of $10 \mu \mathrm{L} / \mathrm{min}$. At the end of each cycle, the surface was regenerated with a $0.1 \mathrm{M}$ glycine- $\mathrm{HCl}$ solution at $\mathrm{pH} 2$.

The equilibrium association constant was calculated in the approximation of equilibrium conditions using the formula:

$$
\operatorname{Req}=(\text { Ka } \cdot C \cdot \operatorname{Rmax}) /(1+\mathrm{Ka} \cdot \mathrm{n} \cdot \mathrm{C})
$$

where Ka is the equilibrium binding constant, Req is the level of binding (signal value on the sensogram, Rmax is the maximum possible level of binding, $\mathrm{C}$ is the concentration of the added antigen, and $\mathrm{n}$ is the steric factor.

The dependence of Req on C was reconstructed in the Scatchard coordinates (1/Req on $1 / C)$. The obtained points were linearized on the Scatchard plot. The point of intersection of the obtained line with the $Y$-axis gives $1 / R \max$, and the tangent of the slope of the linearized dependence is $1 /(\mathrm{Ka} \times \mathrm{Rmax})$. Substituting the obtained $1 / \mathrm{Rmax}$ into the expression $1 /(\mathrm{Ka} \times \mathrm{Rmax})$, the equilibrium association constant was obtained: Ka.

The kinetic dissociation constant was calculated by the formula:

$$
\mathrm{R}=\mathrm{R}_{0} \mathrm{e}^{-\mathrm{kd}(\mathrm{t}-\mathrm{t})}{ }_{0}+\text { Offset }
$$

where $R$ is the signal at the time $t, R_{0}$ is the signal at the beginning of the dissociation section (at the time $t_{0}$ ), and Offset is the background signal.

The kd was found from the $\mathrm{R}$ and $\mathrm{R}_{0}$ obtained from the analysis of the dissociation site on the sensograms.

Considering the ratio $K a=k_{a} / k_{d} ; K d=k_{d} / k_{a}$, the values of $k_{a}$ and $K d$ were found. 


\subsection{Determination of the Concentration of Binding Sites on the Gold Nanoparticles Conjugate}

The conjugate of gold nanoparticles with the Rv0934 antigen, after synthesis and purification from unbound antigen, was concentrated to an optical density of 5 (at a wavelength of $520 \mathrm{~nm}$ ) and mixed with a solution containing $80 \mu \mathrm{g} / \mathrm{mL}$ of monoclonal antibodies HTM81. The mixture was incubated for an hour, then the conjugate with the bound antibodies was separated by centrifugation at $8000 \times g$. The supernatant containing the antibodies unbound to the conjugate was collected and divided into two parts equal in volume. HTM81 was added to the first solution to a concentration of $10 \mu \mathrm{g} / \mathrm{mL}$ as a calibration. Then, the fluorescence of the solutions was measured upon excitation with light at $280 \mathrm{~nm}$ and emission at $350 \mathrm{~nm}$ (the maximum fluorescence of tryptophan in the protein). The difference in fluorescence in the first and second solutions corresponds to fluorescence of $10 \mu \mathrm{g} / \mathrm{mL}$ HTM81. The fluorescence value in the second solution divided by the fluorescence value of $10 \mu \mathrm{g} / \mathrm{mL}$ HTM 81 and multiplied by 10 gives the concentration of unbound antibodies in the sample. Subtracting this concentration from $80 \mu \mathrm{g} / \mathrm{mL}$ gives the concentration of antibodies bound by the conjugate. This value characterizes the concentration of binding sites on the conjugate.

\subsection{Numerical Simulation of an Immunochromatographic Assay}

Numerical simulation was implemented using COPASI 4.19 software (Biocomplexity Institute of Virginia Tech, University of Heidelberg, and University of Manchester) [47].

\section{Results and Discussion (Theoretical)}

\subsection{Modeling Interactions in an Immunochromatographic System}

This paper provides a mathematical description of immunochromatographic serodiagnostics in a format with two antigens using analytical and numerical approaches. In the models, only bivalent immunoglobulins were considered as an analyte, which includes the main class of immunoglobulins: IgG.

At the first stage, a sample containing specific antibodies $(\mathrm{Ab})$ was mixed with a conjugate of an antigen with labeling particles $(\mathrm{P})$ to form complexes of the labeled antigen with one or two valencies of antibodies of $\mathrm{PAb}$ and $\mathrm{P}_{2} \mathrm{Ab}$ composition, respectively:

$$
\begin{gathered}
\mathrm{P}+\mathrm{Ab}=\mathrm{PAb} \\
\mathrm{P}+\mathrm{PAb}=\mathrm{P}_{2} \mathrm{Ab}
\end{gathered}
$$

For simplicity, the formation of complexes of other compositions, potentially containing any amount of $\mathrm{P}$ and $\mathrm{Ab}$, were not considered. Until the analytical zone with the immobilized antigen was reached, only those reactions were carried out proceed. In this case, because the analytical zone is a thin line through which the reagents flows, it can be assumed that the reactions in the analytical zone do not have time to affect the concentrations of free and labeled immunoglobulins. Therefore, the $[\mathrm{P}],[\mathrm{Ab}],[\mathrm{PAb}]$, and $\left[\mathrm{P}_{2} \mathrm{Ab}\right]$ concentrations are determined only by the reactions (1) and (2).

After reaching the analytical zone by the liquid front, three more reactions with the immobilized antigen $(\mathrm{Ag})$ began to proceed in it, expressed by the following Equations:

$$
\begin{gathered}
\mathrm{PAb}+\mathrm{Ag}=\mathrm{PAbAg} \\
\mathrm{Ab}+\mathrm{Ag}=\mathrm{AbAg} \\
\mathrm{P}+\mathrm{AbAg}=\mathrm{PAbAg}
\end{gathered}
$$


The complex of the composition PAbAg was examined. The rate of PAbAg formation determined the kinetic curve of the analysis, and the dependence of the final concentration $[\mathrm{PAbAg}]$ on the initial concentration of antibodies $[\mathrm{Ab}]_{0}$ provided the calibration curve of the analysis (here and below, the index 0 denotes the initial concentrations of the corresponding components). Each of the reactions, (1)-(5), is characterized by its own kinetic and equilibrium association and dissociation constants. Additionally, two time parameters are introduced to describe the system: $t$ is the analysis time from the moment the sample contacts the labeled antigen, and $\mathrm{T}$ is the time from the contact of the sample with the labeled antigen to the contact of the sample with the analytical zone.

To solve the differential equations describing the kinetics of the occurring reactions, a numerical approach was implemented in the COPASI program. The complete system of equations specified in the program is shown in Figure 2:

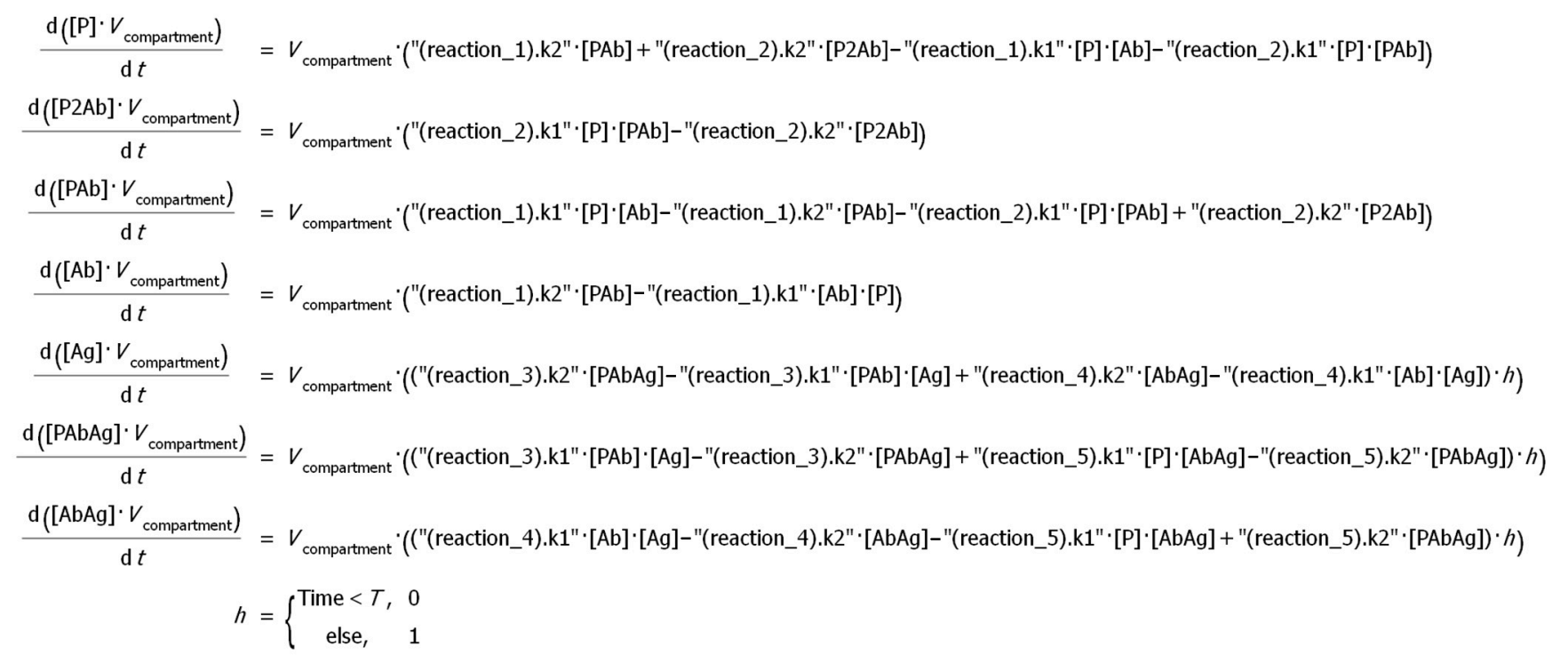

Figure 2. The system of differential equations describing the serodiagnostic lateral flow system with two antigens. k1kinetic constants of association of the corresponding reaction, k2-kinetic constants of dissociation of the corresponding reaction, $h-$ Heaviside function.

\subsection{Formation of $P A b$ and $P_{2} A b$ Complexes}

The antibody detection sensitivity in the considered depends on the ratio of [PAb] and $\left[\mathrm{P}_{2} \mathrm{Ab}\right]$ concentrations. As the $\mathrm{P}_{2} \mathrm{Ab}$ complex does not have free valences for the formation of a detectable PAbAg complex, the formation of $\mathrm{P}_{2} \mathrm{Ab}$ is an undesirable process. For highly sensitive detection of antibodies in a sample, it is necessary to run the assay under conditions that maintain high $[\mathrm{PAb}]$ and low $\left[\mathrm{P}_{2} \mathrm{Ab}\right]$ concentrations.

The system simulated in the COPASI program for arbitrarily chosen concentrations $[\mathrm{Ab}]_{0}$ and $[\mathrm{P}]_{0}$ gives the kinetic curves of $\mathrm{PAb}$ and $\mathrm{P}_{2} \mathrm{Ab}$ formation shown in Figure 3. From the data obtained, it follows that, for the given parameters, the concentration [PAb] will approach the equilibrium value by $90 \%$ in $76 \mathrm{~s}$. At the same time, the concentration of $\left[\mathrm{P}_{2} \mathrm{Ab}\right]$ will approach the equilibrium by $96 \%$. Assuming that the concentrations of [PAb] and $\left[\mathrm{P}_{2} \mathrm{Ab}\right]$ further change insignificantly, the approximation of equilibrium conditions can be applied. This approximation is limited because, with a decrease of the components' concentrations, it will take more time to reach equilibrium conditions. However, the approximation allows for the deriving of symbolic solutions of equations and determining regularities in the system functioning. 


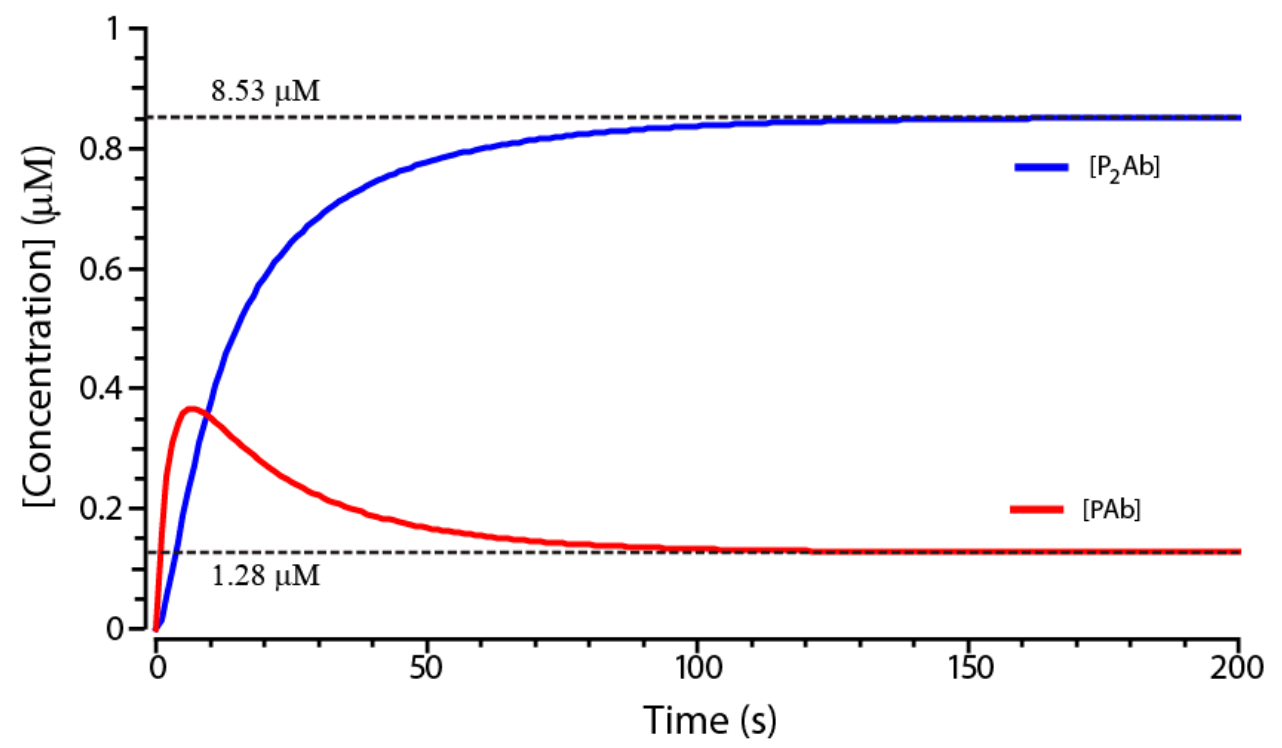

Figure 3. Kinetics of changes in the concentrations of $\mathrm{PAb}$ and $\mathrm{P}_{2} \mathrm{Ab}$ complexes (numerical model in the COPASI program). Model parameters: $\mathrm{T}=60 \mathrm{~s} ;[\mathrm{P}]_{0}=2 \times 10^{-6} \mathrm{M} ;[\mathrm{Ab}]_{0}=10^{-6} \mathrm{M} ; \mathrm{ka} 1=\mathrm{ka} 2=$ $10^{5} 1 /(\mathrm{M} \times \mathrm{s}) ; \mathrm{kd} 1=\mathrm{kd} 2=2.5 \times 10^{-3} 1 / \mathrm{s}$. Dotted lines indicate equilibrium concentrations of [PAb] and $\left[\mathrm{P}_{2} \mathrm{Ab}\right]$.

\subsection{Analytical Model of the Reactions (1) and (2) in Equilibrium Conditions}

The equilibrium condition in the system is given by the expressions:

$$
\begin{aligned}
\mathrm{Ka} 1 & =\frac{[\mathrm{PAb}]}{[\mathrm{P}][\mathrm{Ab}]} \\
\mathrm{Ka} 2 & =\frac{\left[\mathrm{P}_{2} \mathrm{Ab}\right]}{[\mathrm{P}][\mathrm{PAb}]}
\end{aligned}
$$

where Ka1 and Ka2 are equilibrium constants of the reactions (1) and (2), respectively.

Together with the equations of the law of mass conservation, these equations set the equilibrium concentrations of all components of the system:

$$
\begin{aligned}
{[\mathrm{Ab}]_{0} } & =[\mathrm{Ab}]+[\mathrm{PAb}]+\left[\mathrm{P}_{2} \mathrm{Ab}\right] \\
{[\mathrm{P}]_{0} } & =[\mathrm{P}]+[\mathrm{PAb}]+2\left[\mathrm{P}_{2} \mathrm{Ab}\right]
\end{aligned}
$$

After substituting into Equations (8) and (9) the expressions for $\mathrm{PAb}$ and $\mathrm{P}_{2} \mathrm{Ab}$ obtained from (6) and (7), the following was obtained:

$$
\begin{gathered}
{[\mathrm{Ab}]_{0}=[\mathrm{Ab}]\left(1+\mathrm{Ka} 1[\mathrm{P}]+\mathrm{Ka} 1 \mathrm{Ka} 2[\mathrm{P}]^{2}\right)} \\
{[\mathrm{P}]_{0}=[\mathrm{P}](1+\mathrm{Ka} 1[\mathrm{Ab}]+2 \mathrm{Ka} 1 \mathrm{Ka} 2[\mathrm{P}][\mathrm{Ab}])}
\end{gathered}
$$

Substituting into equation (11) the expression for [Ab] obtained from (10), an equation with one unknown $[\mathrm{P}]$ was obtained:

$$
[\mathrm{P}]_{0}=[\mathrm{P}]\left(1+\frac{\mathrm{Ka} 1[\mathrm{Ab}]_{0}(1+2 \mathrm{Ka} 2[\mathrm{P}])}{1+\mathrm{Ka} 1[\mathrm{P}]+\mathrm{Ka} 1 \mathrm{Ka} 2[\mathrm{P}]^{2}}\right)
$$

This equation can be reduced to the form of a cubic equation:

$$
[\mathrm{P}]^{3}+\mathrm{a}[\mathrm{P}]^{2}+\mathrm{b}[\mathrm{P}]+\mathrm{c}=0
$$


where $\mathrm{a}=\mathrm{Kd} 2-[\mathrm{P}]_{0}+2[\mathrm{Ab}]_{0}, \mathrm{~b}=\mathrm{Kd} 2 \times\left(\mathrm{Kd} 1-[\mathrm{P}]_{0}+[\mathrm{Ab}]_{0}\right)$ and $\mathrm{c}=-\mathrm{Kd} 1 \times \mathrm{Kd} 2 \times[\mathrm{P}]_{0}$.

For convenience, the equilibrium association constants $\mathrm{Ka} 1$ and $\mathrm{Ka} 2$ were replaced by their reciprocal values - the equilibrium dissociation constants $\mathrm{Kd} 1$ and $\mathrm{Kd} 2$, respectively.

To solve the cubic equation, Vieta's trigonometric formulas was used, according to the recommendations of Wang [48].

$$
[P]=-\frac{a}{3}+\frac{2}{3} \sqrt{\left(a^{2}-3 b\right)} \cos \frac{\theta}{3}
$$

where $\theta=\arccos \frac{-2 a^{3}+9 a b-27 c}{2 \sqrt{\left(a^{2}-3 b\right)^{3}}}$.

This solution gives the equilibrium concentration [P]. Substituting it into equation (10), the equilibrium concentration $[\mathrm{Ab}]$ was found. Next, substituting the values $[\mathrm{P}]$ and $[\mathrm{Ab}]$ into equation (6), the equilibrium value [PAb] was found, and the obtained values $[\mathrm{PAb}]$ and $[\mathrm{P}]$ give the equilibrium concentration $\left[\mathrm{P}_{2} \mathrm{Ab}\right]$ from Equation (7).

Dependences of equilibrium concentrations $[\mathrm{PAb}]$ and $\left[\mathrm{P}_{2} \mathrm{Ab}\right]$ on the initial concentration of labeled antigen $[\mathrm{P}]_{0}$, shown in Figure 4 , demonstrate that, if the $[\mathrm{P}]_{0}$ is close to the concentration of the antibodies to be detected, then the equilibrium concentration of [PAb] will be maximum. At lower $[\mathrm{P}]_{0}$, the $[\mathrm{PAb}]$ concentration decreases due to a lack of labeled antigen, and, at higher $[\mathrm{P}]_{0}$, most of the antibodies and labeled antigen were contained in the $\mathrm{P}_{2} \mathrm{Ab}$ complex, which is unable to bind in the assay zone. Moreover, as shown by curves 1, 3, 5, and 7 in Figure 4, this dependence is not contingent on the values and ratio of the equilibrium complexation constants of reactions (1) and (2).

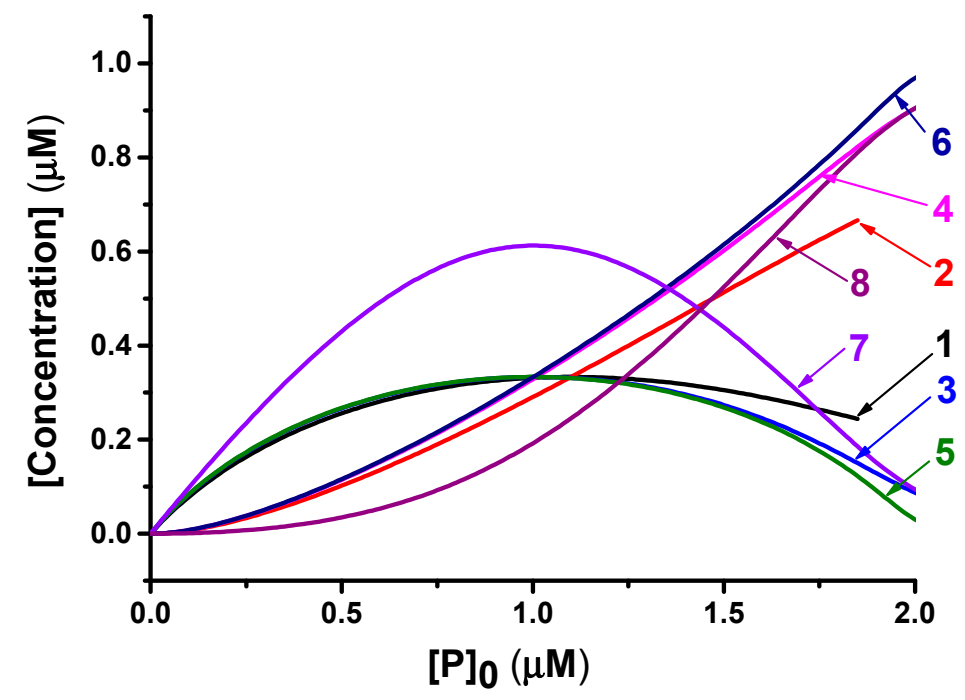

Figure 4. Equilibrium concentrations of $\mathrm{PAb}$ and $\mathrm{P}_{2} \mathrm{Ab}$ complexes. Model parameters: $[\mathrm{Ab}]_{0}=1 \mu \mathrm{M}$; 1. $[\mathrm{PAb}]$ at $\mathrm{Kd} 1=\mathrm{Kd} 2=0.1 \mu \mathrm{M}$; 2. $\left[\mathrm{P}_{2} \mathrm{Ab}\right]$ at $\mathrm{Kd} 1=\mathrm{Kd} 2=0.1 \mu \mathrm{M}$; 3. [PAb] at $\mathrm{Kd} 1=\mathrm{Kd} 2=0.01 \mu \mathrm{M}$; 4. $\left[\mathrm{P}_{2} \mathrm{Ab}\right]$ at $\mathrm{Kd} 1=\mathrm{Kd} 2=0.01 \mu \mathrm{M} ;$ 5. $[\mathrm{PAb}]$ at $\mathrm{Kd} 1=\mathrm{Kd} 2=0.001 \mu \mathrm{M} ; \mathbf{6} .\left[\mathrm{P}_{2} \mathrm{Ab}\right]$ at $\mathrm{Kd} 1=\mathrm{Kd} 2=0.001 \mu \mathrm{M}$; 7. $[\mathrm{PAb}]$ at $\mathrm{Kd} 1=0.001 \mu \mathrm{M}, \mathrm{Kd} 2=0.01 \mu \mathrm{M} ; 8 .\left[\mathrm{P}_{2} \mathrm{Ab}\right]$ at $\mathrm{Kd} 1=0.001 \mu \mathrm{M}, \mathrm{Kd} 2=0.01 \mu \mathrm{M}$.

This model predicts the existence of an optimal relationship between $[\mathrm{Ab}]_{0}$ and $[\mathrm{P}]_{0}$. However, it should be taken into account that the formation of a colored complex in the analytical zone can also occur according to reaction (4), and the maximum concentration of [PAb] promotes only the formation of PAbAg according to reaction (3). Therefore, the optimal ratio of $[\mathrm{Ab}]_{0}$ and $[\mathrm{P}]_{0}$ in a real system will differ from 1:1. However, in any case, the formation of a $\mathrm{P}_{2} \mathrm{Ab}$ complex decreases the sensitivity of antibody detection. Optimization of system parameters should be aimed at minimizing the effect of reaction (2) on the assay results. 


\section{Results and Discussion (Experimental)}

\subsection{Overview}

For the model to adequately describe the real system, it is necessary to substitute into the equations the parameters (complexation constants, component concentrations, time parameters) that are as close as possible to real ones. For this, it is necessary to conduct an experimental study of these parameters.

Time parameters can be measured directly by observing the movement of the liquid front and the colored marker along the test strip membranes. Determination of constants and concentrations requires a more complex technique. To measure them, a model immunochromatographic test system was made for the determination of specific antibodies against the Rv0934 protein. Solutions containing known concentrations of HTM81 monoclonal antibodies against this antigen were used as model samples.

\subsection{Characterization of the Preparation of Gold Nanoparticles}

The dimensional parameters of the obtained gold nanoparticles were evaluated using the transmission electron microscopy. Particle images were obtained at a magnification of 66,000 . Table 1 contains the data obtained after analyzing the photographs. The average particle diameter was $22.8 \mathrm{~nm}$ for a sample of 210 particles. The resulting preparation was stable, and no aggregates were observed.

Table 1. Characterization of the particle size and homogeneity of the obtained preparation of gold nanoparticles.

\begin{tabular}{cccc}
\hline & Major Axis Length $(\mathbf{n m})$ & Minor Axis Length $(\mathbf{n m})$ & Axis Ratio \\
\hline Average diameter $(\mathrm{nm})$ & 22.8 & 18.5 & 0.845 \\
\hline Standard deviation $(\mathrm{nm})$ & 4.1 & 2.9 & 0.095 \\
\hline
\end{tabular}

\subsection{Determination of the Constants of Immune Interaction}

Sensograms of the interaction of antigen with antibodies were obtained using the surface plasmon resonance sensor BIAcore $X$, passing over the surface of the optical chip with immobilized antibodies HTM81 solutions containing from 0.5 to $50 \mu \mathrm{g} / \mathrm{mL}$ of Rv0934 antigen (Figure 5).

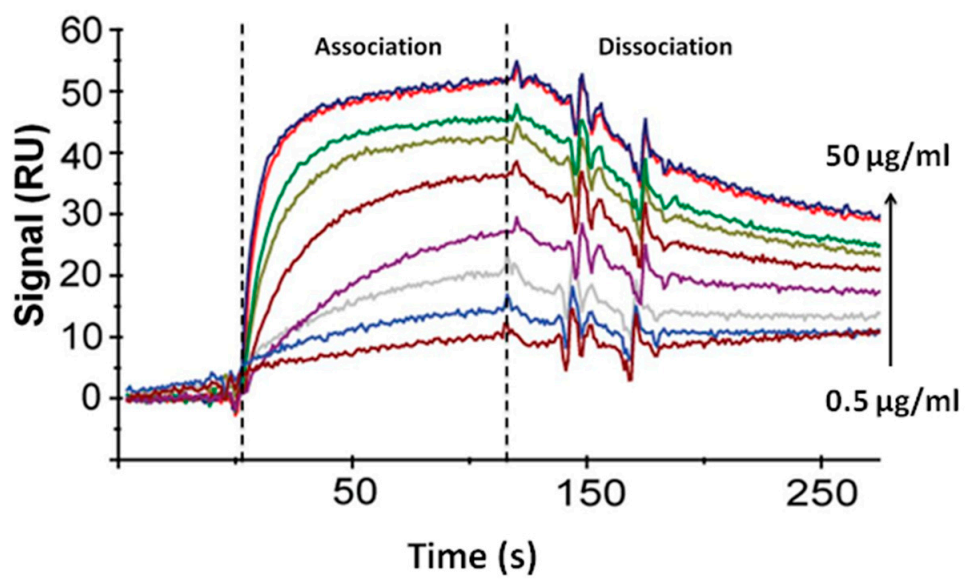

Figure 5. Sensograms of the interaction of the Rv0934 antigen with the surface of the CM5 chip modified with the HTM81 antibodies. Antigen concentration $0.5 ; 1 ; 3 ; 5 ; 10 ; 20 ; 30 ; 40 ;$ and $50 \mu \mathrm{g} / \mathrm{mL}$. Dotted lines show the beginning and end of the time interval for the flow of antigen solutions through the sensor cell. The signal is the difference between RU values in the analytical cell and the comparison cell. 
Using the equilibrium conditions approximation, the equilibrium association constant (Ka) was determined via the Scatchard method based on an analysis of association sensograms. Then, the kinetic dissociation constant $(\mathrm{kd})$ was found from the dissociation curves of immune complexes. After finding $\mathrm{Ka}$ and $\mathrm{kd}$, the kinetic association constant (ka) and the equilibrium dissociation constant (Kd) were calculated using the expressions $\mathrm{Ka}=\mathrm{ka} / \mathrm{kd} ; \mathrm{Kd}=\mathrm{kd} / \mathrm{ka}$. Table 2 provides the values of kinetic and equilibrium constants for the studied antigen-antibody pair.

Table 2. Kinetic and equilibrium constants of the interaction of the Rv0934 antigen with monoclonal antibodies HTM81.

\begin{tabular}{cccc}
\hline ka (1/Ms) & kd (1/s) & Ka (1/M) & Kd (M) \\
\hline $1.08 \times 10^{5}$ & $2.54 \times 10^{-3}$ & $4.27 \times 10^{7}$ & $2.34 \times 10^{-8}$ \\
\hline
\end{tabular}

\subsection{Determination of the Concentration of the Labeled Antigen}

When antigen is conjugated to label particles, excessive amounts of antigen are usually used to maximize the binding capacity of the conjugate. In addition, part of the antigen loses binding activity due to the covering of epitopes by label particles. For this reason, the concentration of binding sites on the label conjugate is unknown. To determine this value, a technique based on measuring the fluorescence of tryptophan residues in antibodies was used. Determination of protein concentration based on tryptophan fluorescence was described in detail in our previous work [49].

The Rv0934 protein conjugated to gold nanoparticles (optical density at $520 \mathrm{~nm}$ was equal to 2) was mixed with a solution containing $80 \mu \mathrm{g} / \mathrm{mL}$ of antibodies (excessive concentration, since Rv0934 was conjugated to nanoparticles at a concentration of $10 \mu \mathrm{g} / \mathrm{mL}$ per 1 optical density unit). After incubation, the formed complexes with nanoparticles were separated via centrifugation, and the fluorescence of tryptophan in the solution was measured. Comparing the obtained value with the fluorescence of the calibration solution, the concentration of the remaining antibodies was calculated, which was $66 \mu \mathrm{g} / \mathrm{mL}$. That is, the conjugate bound $14 \mu \mathrm{g} / \mathrm{mL}$ antibodies $(93 \mathrm{nM})$ were at an optical density of 2 .

\subsection{Experimental Verification of Theoretical Relationships}

Theoretical modeling of this system predicts the appearance of the so-called hook effect on the calibration curve-a drop in the signal at high analyte concentrations (Figure 6A). This effect, confirmed experimentally (see Figure 6B), is associated with the fact that the antibodies block all antigen on the marker (gold nanoparticles), and the antibody excess remains in the solution. After the solution reaches the analytical zone, free and label-bound antibodies begin to compete to bind with the immobilized antigen, which leads to a decrease in coloration. Experimental confirmation of the theoretically predicted effect demonstrates the predictive capabilities of the developed model.

As seen in Figure 6, with the indicated parameters of the immunoreactants, the position of the maximum on the calibration curve shifts with time toward lower concentrations, but stabilizes in about $3 \mathrm{~min}$. Note that the model predicts the position of the maximum of the calibration dependence at lower concentrations than observed in the experiment. This may be due to the simplifications introduced into the model, as well as the fact that the concentration of active antibodies in the preparation is somewhat lower than their total concentration. 


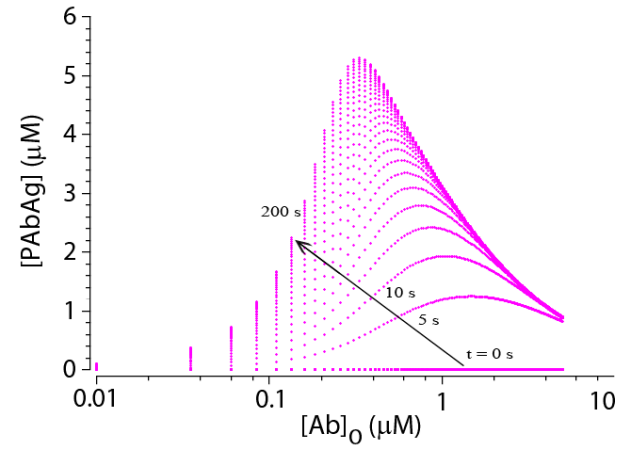

(A)

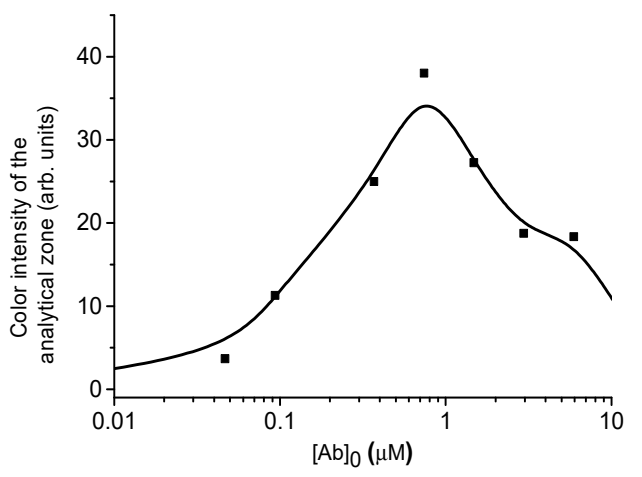

(B)

Figure 6. Calibration dependences of analyte determination. (A) Theoretical calibration dependence obtained by numerical modeling. Model parameters: $\mathrm{T}=60 \mathrm{~s} ;[\mathrm{P}]_{0}=5 \times 10^{-7} \mathrm{M} ;[\mathrm{Ag}]_{0}=10^{-5} \mathrm{M} ; \mathrm{ka}=10^{5} 1 /\left(\mathrm{M}^{*} \mathrm{~s}\right) ; \mathrm{kd}=2.5 \times 10^{-3} 1 / \mathrm{s}$. (B). Experimental values of the color intensity of the analytical zones after the assay (signal from the Reflekom analyzer).

In real samples, the concentration of specific antibodies against individual antigens rarely exceeds $2 \mu \mathrm{M}$, even in hyperimmune sera [36]. Therefore, a decrease in the color intensity to an undetectable limit is unlikely. In addition, the influence of the hook effect on the analysis results can be eliminated by diluting the sample.

As already noted, one of the ways to control the sensitivity of the assay is to optimize the concentration of the labeled antigen. To verify this assumption, a series of test strips were made with different amounts of added antigen-gold nanoparticle conjugate, and a solution containing $20 \mu \mathrm{g} / \mathrm{mL}$ of antibodies was analyzed. The theoretical dependence calculated in the COPASI program (see Figure 7A) predicts the appearance of a maximum at the point corresponding to a twofold excess of the $[\mathrm{P}]_{0}$ concentration relative to the concentration of added antibodies. The experimental dependence had a similar shape and confirmed the existence of the optimal concentration of the labeled antigen (see Figure 7B). However, according to the calculated concentration of the active antigen on nanoparticles, the maximum of the obtained dependence turned out to be lower than that predicted by the model. This fact can also be associated with a partial loss of the antibody activity during storage, as well as with the influence of factors not taken into account by the model-for example, the possibility of the formation of complexes of a more complicated composition.

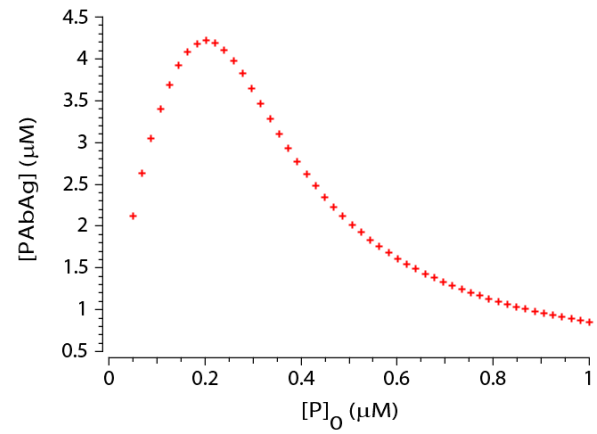

(A)

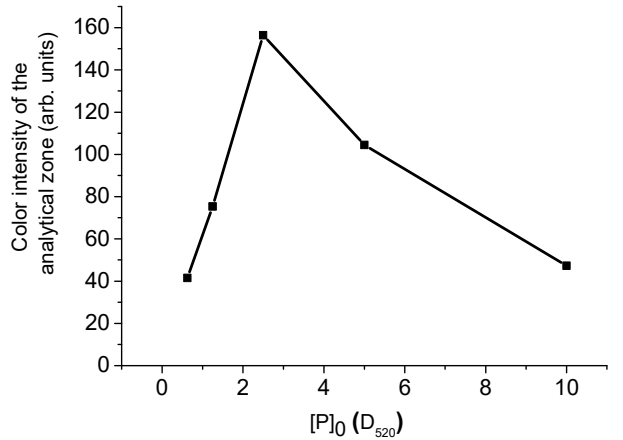

(B)

Figure 7. Dependences of analyte determination at different concentrations of labeled antigen (A) Theoretical dependence obtained by numerical simulation. Model parameters: $\mathrm{T}=60 \mathrm{~s} ;[\mathrm{P}]_{0}=5 \times 10^{-7} \mathrm{M} ;[\mathrm{Ag}]_{0}=10^{-5} \mathrm{M} ; \mathrm{ka}=10^{5} 1 /\left(\mathrm{M}^{*} \mathrm{~s}\right)$; $\mathrm{kd}=2.5 \times 10^{-3} 1 / \mathrm{s}$. (B). Experimental values of the color intensity (signal from the Reflekom analyzer) of analytical zones after the assay at different optical densities (D520) of the label conjugate. 
Another parameter that affects the sensitivity of the system is the concentration of the immobilized antigen in the analytical zone $[\mathrm{Ag}]_{0}$. In this case, it is obvious that an increase in $[\mathrm{Ag}]_{0}$ leads to an acceleration of the formation of PAbAg both by reactions (3) and (5). Therefore, an increase in the sensitivity and assay signal presupposes the use of the maximum possible antigen concentrations in the analytical zone and is limited only by the sorption capacity of the working membrane (depending on the brand and manufacturer). This assumes, however, the complete absence of nonspecific interaction in the system. If there is such an interaction, it will limit the analytical characteristics of the assay. Figure 8 shows the appearance of the analytical zones of the test strips after the determination of antibodies for three concentrations of the immobilized antigen. According to the study conducted by Merck-Millipore employees, the sorption capacity of immunochromatographic nitrocellulose membranes varies in the range of 4-15 mg/mL (https://www.merckmillipore.com/RU/ru/products/ivd-oem-materialsreagents/lateral-flow-membranes/n6mb.qB.LOYAAAE_gut3.Lxi,nav). This study was carried out using the example of immunoglobulins G; however, since the molecular weight and volume are approximately proportional for globular proteins, this amount will be similar for other proteins.

\begin{tabular}{lllll}
\hline Concentration ot the immobilized antigen $(\mathrm{mg} / \mathrm{ml})$ & 1 & 2 & 5 \\
\hline \multicolumn{2}{c}{$\mathrm{C} \rightarrow$} & & & \\
\hline \\
Appearance of the zones after assay & $\mathrm{A} \rightarrow$ & & \\
\hline
\end{tabular}

Figure 8. Influence of concentration of the immobilized antigen on the coloration of analytical zone (appearance of working membranes for antibody concentration $200 \mathrm{ng} / \mathrm{mL}$, D520 of the antigen conjugate with gold nanoparticles-2). A-analytical zone; C-control zone.

\section{Conclusions}

Utilizing immunochromatographic serodiagnostics with two antigens appears to be effective for detecting specific immunoglobulins against the background of a multiple excess of total immunoglobulins in the sample. Unlike other formats of immunochromatographic serodiagnostics, this format has not received a theoretical description. In our work, a mathematical model of immunochemical interactions in the system was proposed, which makes it possible to assess the influence of the parameters of immunochemical reactions on the analysis results. This model allows for the formulation of predictions in the behavior of the analytical system and provides recommendations for increasing the sensitivity of antibody detection. The model predicts that the detection limit for antibodies can be reduced if the following are done:

1. Use the concentration of the labeled antigen with approximately twice the concentration of active antibodies in the sample. As the concentration of antibodies against the antigen used is initially unknown, it is necessary to experimentally titrate the amount of labeled antigen to achieve the target sensitivity. 
2. Use the highest possible concentration of the immobilized antigen in the analytical zone, but not exceeding the sorption capacity of the working membrane.

The stated regularities were demonstrated in the system for the determination of specific immunoglobulins against the Mycobacterium tuberculosis Rv0934 protein. However, the recommendations are of a general nature and can be applied to improve other analytical systems based on the principle of double-antigen sandwich immunochromatographic serodiagnostics.

Author Contributions: Conceptualization, D.V.S., A.V.Z. and B.B.D.; investigation, D.V.S.; methodology, D.V.S., A.V.Z. and B.B.D.; resources, D.V.S.; validation, D.V.S.; visualization, D.V.S. and A.V.Z.; writing (original draft), D.V.S., A.V.Z. and B.B.D.; Writing (review and editing), D.V.S., A.V.Z. and B.B.D. All authors have read and agreed to the published version of the manuscript.

Funding: The work was financially supported by the Ministry of Science and Higher Education of the Russian Federation (theoretical description of intermolecular interactions) and the Russian Science Foundation (grant 16-15-00245; experimental verification of theoretical relationships).

Data Availability Statement: Data is contained within the article. The created COPASI file for modelling, data of calculations and verifications are available on request from the corresponding author.

Acknowledgments: This study was conducted using the Shared-Access Equipment Centre "Industrial Biotechnology" of the Federal Research Centre "Fundamentals of Biotechnology" Russian Academy of Sciences (A.N. Bach Institute of Biochemistry), Moscow, Russia.

Conflicts of Interest: The authors declare no conflict of interest.

\section{References}

1. Parija, S.C. Textbook of Microbiology E Immunology-E-Book; Reed Elsevier India Pvt. Ltd.: Maharashtra, India, $2014 ;$ p. 684.

2. Tille, P. Bailey \& Scott's Diagnostic Microbiology-E-Book; Elsevier Health Sciences: New York, NY, USA, 2013 ; p. 1056.

3. Hamilton, R.G.; Hemmer, W.; Nopp, A.; Kleine-Tebbe, J. Advances in IgE testing for diagnosis of allergic disease. J. Allergy Clin. Immunol. Pract. 2020, 8, 2495-2504. [CrossRef]

4. Mohiuddin, M. Tuberculosis-burden and serodiagnosis. IMC J. Med. Sci. 2020, 14, 59-69. [CrossRef]

5. Jenabian, M.A.; Costiniuk, C.T.; Talla, P.; Robin, L.; Tonen Wolyec, S.; Mboumba Bouassa, R.S.; Bélec, L. Potential for False-Positive Results with Serological Assays for HIV in Central Africa: Implications for the HIV Serodiagnosis Algorithm According to the 2015 Consolidated WHO Recommendations for Resource-Constrained Countries. AIDS Res. Hum. Retrovir. 2017, 33, 1077-1079. [CrossRef]

6. $\quad$ Feng, X.; Xiu, B.; Chen, K.; Yang, X.; Zhang, H.; Yue, J.; Tan, Y.; Li, H.; Nicholson, R.A.; Tam, A.W.; et al. Enhanced serodiagnostic utility of novel Mycobacterium tuberculosis polyproteins. J. Infect. 2013, 66, 366-375. [CrossRef]

7. Mani, V.; Paleja, B.; Larbi, K.; Kumar, P.; Tay, J.A.; Siew, J.Y.; Inci, F.; Wang, S.; Chee, C.; Wang, Y.T.; et al. Microchip-based ultrafast serodiagnostic assay for tuberculosis. Sci. Rep. 2016, 6, 35845. [CrossRef]

8. Mezzasoma, L.; Bacarese-Hamilton, T.; Di Cristina, M.; Rossi, R.; Bistoni, F.; Crisanti, A. Antigen microarrays for serodiagnosis of infectious diseases. Clin. Chem. 2002, 48, 121-130. [CrossRef]

9. Cheng, M.P.; Yansouni, C.P.; Basta, N.E.; Desjardins, M.; Kanjilal, S.; Paquette, K.; Caya, C.; Semret, M.; Quach, C.; Libman, M.; et al. Serodiagnostics for severe acute respiratory syndrome-related Coronavirus 2: A narrative review. Ann. Intern. Med. 2020, 173, 450-460. [CrossRef]

10. Pecora, N.D.; Zand, M.S. Measuring the serologic response to severe acute respiratory syndrome coronavirus 2: Methods and meaning. Clin. Lab. Med. 2020, 40, 603-614. [CrossRef]

11. Bastos, M.L.; Tavaziva, G.; Abidi, S.K.; Campbell, J.R.; Haraoui, L.P.; Johnston, J.C.; Lan, Z.; Law, S.; MacLean, E.; Trajman, A.; et al. Diagnostic accuracy of serological tests for covid-19: Systematic review and meta-analysis. BMJ 2020, 370, m2516. [CrossRef]

12. Lehman, D.C. Immunodiagnosis of Infectious Diseases. In Textbook of Diagnostic Microbiology, 4th ed.; Mahon, C., Lehman, D., Eds.; Saunders: Yonkers, NY, USA, 2014; p. 200.

13. Kozel, T.R.; Burnham-Marusich, A.R. Point-of-Care testing for infectious diseases: Past, present, and future. J. Clin. Microbiol. 2017, 55, 2313-2320. [CrossRef]

14. Hanafiah, K.M.; Garcia, M.; Anderson, D. Point-of-care testing and the control of infectious diseases. Biomark. Med. 2013, 7, 333-347. [CrossRef] [PubMed]

15. Katoba, J.; Kuupiel, D.; Mashamba-Thompson, T.P. Toward improving accessibility of point-of-care diagnostic services for maternal and child health in low- and middle-income countries. Point Care 2019, 18, 17-25. [CrossRef] [PubMed]

16. Riccò, M.; Ferraro, P.; Gualerzi, G.; Ranzieri, S.; Henry, B.M.; Said, Y.B.; Pyatigorskaya, N.; Nevolina, E.; Wu, J.; Bragazzi, N.L.; et al. Point-of-Care diagnostic tests for detecting SARS-CoV-2 antibodies: A systematic review and meta-analysis of real-world data. J. Clin. Med. 2020, 9, 1515. [CrossRef] [PubMed] 
17. Reali, S.; Najib, E.Y.; Balázs, K.E.T.; Tan, A.C.H.; Váradi, L.; Hibbs, D.E.; Groundwater, P.W. Novel diagnostics for point-of-care bacterial detection and identification. RSC Adv. 2019, 9, 21486-21497. [CrossRef]

18. Heidt, B.; Siqueira, W.F. Point of care diagnostics in resource-limited settings: A review of the present and future of PoC in its most needed environment. Biosensors 2020, 10, 133. [CrossRef]

19. Quesada-González, D.; Merkoçi, A. Nanoparticle-based lateral flow biosensors. Biosens. Bioelectron. 2015, 73, 47-63. [CrossRef]

20. Huang, X.; Aguilar, Z.P.; Xu, H.; Lai, W.; Xiong, Y. Membrane-based lateral flow immunochromatographic strip with nanoparticles as reporters for detection: A review. Biosens. Bioelectron. 2016, 75, 166-180. [CrossRef]

21. Goryacheva, I.Y.; Lenain, P.; De Saeger, S. Nanosized labels for rapid immunotests. Trends Analyt. Chem. 2013, 46, 30-43. [CrossRef]

22. Van Amerongen, A.; Veen, J.; Arends, H.A.; Koets, M. Lateral Flow Immunoassays. In Handbook of Immunoassay Technologies, 1st ed.; Vashist, S.K., Luong, J.H.T., Eds.; Academic Press: Cambridge, MA, USA, 2018; pp. 157-182.

23. Soh, J.H.; Chan, H.-M.; Ying, J.Y. Strategies for developing sensitive and specific nanoparticle-based lateral flow assays as point-of-care diagnostic device. Nano Today 2020, 30, 100831. [CrossRef]

24. Abdoel, T.; Dias, I.T.; Cardoso, R.; Smits, H.L. Simple and rapid field tests for brucellosis in livestock. Vet. Microbiol. 2008, 130, 312-319. [CrossRef]

25. Sotnikov, D.V.; Byzova, N.A.; Zherdev, A.V.; Eskendirova, S.Z.; Baltin, K.K.; Mukanov, K.K.; Ramankulov, E.M.; Sadykhov, E.G.; Dzantiev, B.B. Express immunochromatographic detection of antibodies against Brucella abortus in cattle sera based on quantitative photometric registration and modulated cut-off level. J. Immunoass. Immunochem. 2015, 36, 80-90. [CrossRef] [PubMed]

26. Nakano, S.; Tsukimura, T.; Togawa, T.; Ohashi, T.; Kobayashi, M.; Takayama, K.; Kobayashi, Y.; Abiko, H.; Satou, M.; Nakahata, T.; et al. Rapid immunochromatographic detection of serum Anti- $\alpha$-Galactosidase A antibodies in fabry patients after enzyme replacement therapy. PLoS ONE 2015, 10, e0128351. [CrossRef] [PubMed]

27. Janwan, P.; Intapan, P.M.; Yamasaki, H.; Rodpai, R.; Laummaunwai, P.; Thanchomnang, T.; Sanpool, O.; Kobayashi, K.; Takayama, K.; Kobayashi, Y.; et al. Development and usefulness of an immunochromatographic device to detect antibodies for rapid diagnosis of human gnathostomiasis. Parasit. Vectors 2016, 9, 14. [CrossRef] [PubMed]

28. Struyf, F.; Lemmens, A.; Valadas, E.; Verhaegen, J.; Van Ranst, M. Usefulness of immunochromatographic detection of antibodies to mycobacterium tuberculosis as an adjunct to auramine staining for rapid diagnosis of tuberculosis in a low-prevalence setting. Eur. J. Clin. Microbiol. Infect. Dis. 1999, 18, 740-742. [CrossRef]

29. Schrier, W.H.; Schoengold, R.J.; Baker, J.T.; Norell, J.L.; Jaseph, C.L.; Okin, Y.; Doe, J.Y.; Chandler, H. Development of FlexSure ${ }^{\circledR}$ HP-An immunochromatographic method to detect antibodies against Helicobacter pylori. Clin. Chem. 1998, 44, 293-298. [CrossRef]

30. Sotnikov, D.V.; Berlina, A.N.; Zherdev, A.V.; Eskendirova, S.Z.; Mukanov, K.K.; Ramankulov, Y.M.; Eskendirova, S.Z.; Mukantayev, K.N.; Dzantiev, B.B. Comparison of three schemes of quantum dots-based immunochromatography for serodiagnosis of brucellosis in cattle. J. Eng. Stud. Res. 2019, 14, 3711-3718. [CrossRef]

31. Kemper, M.J.; Altrogge, H.; Ganschow, R.; Müller-Wiefel, D.E. Serum levels of immunoglobulins and IgG subclasses in steroid sensitive nephrotic syndrome. Pediatr. Nephrol. 2002, 17, 413-417. [CrossRef]

32. Rajerison, M.; Dartevelle, S.; Ralafiarisoa, L.A.; Bitam, I.; Tuyet, D.T.N.; Andrianaivoarimanana, V.; Nato, F.; Rahalison, L. Development and evaluation of two simple, rapid immunochromatographic tests for the detection of Yersinia pestis antibodies in humans and reservoirs. PLoS Negl. Trop. Dis. 2009, 3, e421. [CrossRef]

33. Karakus, C.; Salih, B.A. Comparison of the lateral flow immunoassays (LFIA) for the diagnosis of Helicobacter pylori infection. J. Immunol. Methods 2013, 396, 8-14. [CrossRef]

34. Martínez-Sernández, V.; Muino, L.; Perteguer, M.J.; Garate, T.; Mezo, M.; Gonzalez-Warleta, M.; Muro, A.; Correia da Costa, J.M.; Romaris, F.; Ubeira, F.M. Development and evaluation of a new lateral flow immunoassay for serodiagnosis of human fasciolosis. PLoS Negl. Trop. Dis. 2011, 5, e1376. [CrossRef]

35. Ben-Selma, W.; Harizi, H.; Boukadida, J. Immunochromatographic IgG/IgM test for rapid diagnosis of active tuberculosis. Clin. Vaccine Immunol. 2011, 18, 2090-2094. [CrossRef] [PubMed]

36. Sotnikov, D.V.; Zherdev, A.V.; Dzantiev, B.B. Theoretical and experimental comparison of different formats of immunochromatographic serodiagnostics. Sensors 2017, 18, 36. [CrossRef] [PubMed]

37. Sotnikov, D.V.; Zherdev, A.V.; Avdienko, V.G.; Dzantiev, B.B. Immunochromatographic assay for serodiagnosis of tuberculosis using an antigen-colloidal gold conjugate. Appl. Biochem. Microbiol. 2015, 51, 834-839. [CrossRef]

38. Wu, H.S.; Chiu, S.C.; Tseng, T.C.; Lin, S.F.; Lin, J.H.; Hsu, Y.H.; Wang, M.C.; Lin, T.L.; Yang, W.Z.; Ferng, T.L.; et al. Serologic and molecular biologic methods for SARS-associated coronavirus infection, Taiwan. Emerg. Infect. Dis. 2004, 10, 304-310. [CrossRef]

39. Sato, N.S.; Melo, C.S.D.; Zerbini, L.C.; Silveira, E.P.; Fagundes, L.J.; Ueda, M. Assessment of the rapid test based on an immunochromatography technique for detecting anti-Treponema pallidum antibodies. Rev. Inst. Med. Trop. Sao Paulo 2003, 45, 319-322. [CrossRef]

40. Vrublevskaya, V.V.; Afanasyev, V.N.; Grinevich, A.A.; Skarga, Y.Y.; Gladyshev, P.P.; Ibragimova, S.A.; Krylsky, D.V.; Dezhurov, S.V.; Morenkov, O.S. A sensitive and specific lateral flow assay for rapid detection of antibodies against glycoprotein B of Aujeszky's disease virus. J. Virol. Methods 2017, 249, 175-180. [CrossRef]

41. Berli, C.L.A.; Kler, P.A. A quantitative model for lateral flow assays. Microfluid. Nanofluid. 2016, 20, 104. [CrossRef] 
42. Gasperino, D.; Baughman, T.; Hsieh, H.V.; Bell, D.; Weigl, B.H. Improving lateral flow assay performance using computational modeling. Annu. Rev. Anal. Chem. 2018, 11, 219-244. [CrossRef]

43. Schaumburg, F.; Kler, P.A.; Berli, C.L.A. Numerical prototyping of lateral flow biosensors. Sens. Act. B Chem. 2018, 259 , 1099-1107. [CrossRef]

44. Gasperino, D.J.; Leon, D.; Lutz, B.; Cate, D.M.; Nichols, K.P.; Bell, D.; Weigl, B.H. Threshold-based quantification in a multiline lateral flow assay via computationally designed capture efficiency. Anal. Chem. 2018, 90, 6643-6650. [CrossRef]

45. Liu, Z.; Qu, Z.; Tang, R.; He, X.; Yang, H.; Bai, D.; Xu, F. An improved detection limit and working range of lateral flow assays based on a mathematical model. Analyst 2018, 143, 2775-2783. [CrossRef] [PubMed]

46. Sotnikov, D.V.; Zherdev, A.V.; Dzantiev, B.B. Mathematical modeling of bioassays. Biochemistry (Moscow) 2017, 82, 1744-1766. [CrossRef] [PubMed]

47. Hoops, S.; Sahle, S.; Gauges, R.; Lee, C.; Pahle, J.; Simus, N.; Singhal, M.; Xu, L.; Mendes, P.; Kummer, U. COPASI—A complex pathway simulator. Bioinformatics 2006, 22, 3067-3074. [CrossRef] [PubMed]

48. Wang, Z.X. An exact mathematical expression for describing competitive binding of two different ligands to a protein molecule. FEBS Lett. 1995, 360, 111-114. [CrossRef]

49. Sotnikov, D.V.; Zherdev, A.V.; Dzantiev, B.B. Development and application of a label-free fluorescence method for determining the composition of gold nanoparticle-protein conjugates. Int. J. Mol. Sci. 2014, 16, 907-923. [CrossRef] [PubMed] 